Received: 12 September 2017

Accepted: 24 October 2018

Published online: 27 November 2018

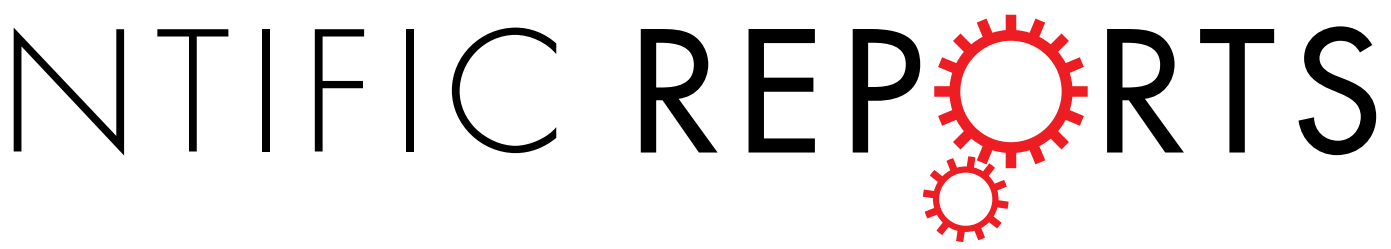

\section{OPEN Copper and other heavy metals in grapes: a pilot study tracing influential factors and evaluating potential risks in China}

\author{
Xiaomin Li, Shujun Dong \& Xiaoou Su
}

In this study, grapes (Vitis vinifera L.) were systematically sampled across the main grape-producing areas in a nationwide survey of China. Grapes from special regions, such as heavy metal polluted areas (e-waste dismantling area) and pesticide free areas (courtyard) were also collected to make a comparison. Grape skins and pulps were separated to evaluate influence of accumulation behavior, environmental transport and water cleaning efficiency to heavy metals. Levels of copper in grape skins $(5.02 \pm 3.18 \mu \mathrm{g} / \mathrm{g})$ were higher than in pulps $(3.74 \pm 1.48 \mu \mathrm{g} / \mathrm{g})$. Only high level of copper in two grape skins (sampled from an e-waste dismantling area) showed obvious decrease during water clean-up procedure, indicating the influence of air deposition. Statistical analysis showed no significant difference in the copper levels of grapes from markets, courtyards and e-waste dismantling areas. Concentrations and sources of chromium (Cr), manganese (Mn), nickel (Ni), cadmium (Cd), lead (Pb) and arsenic (As) were also analyzed. Higher levels of these heavy metals were observed in grape skins than pulps. Finally, we evaluated the risk of ingesting heavy metal through grapes using the estimated daily intake (EDI). No health risk was found by consuming grapes according to the data from this study.

Grape (Vitis vinifera L.) is one of the most widely consumed fruits around the world. It is not only a popular table fruit, but is also the raw material to produce wine worldwide. Recent studies have suggested that the good cardiac health condition of inhabitants around the Mediterranean area was related to rich content of phenolic compounds in grapes from their diet $^{1,2}$, which might further promote grape consumption. As known, viticulture will be abundantly applied with copper-based pesticide, because this kind of plants is vulnerable to fungal diseases (e.g. downy mildew). In order to control downy mildew, about 400-800 kg per hectare of Bordeaux mixture (mixture of quicklime and copper sulfate, the concentration of copper is about $2.55 \mathrm{~g} / \mathrm{L}$ ) was sprayed several times during the whole grape growing season ${ }^{3}$. During the process of which, the sprayed copper pesticide can be deposited on the fruit surfaces and might find its way into the fruit tissues. Soil in vineyards was also considered to be a seriously copper polluted area due to year by year application of Bordeaux mixture ${ }^{4-7}$. The copper could also be able to transport to grapes through root adsorption. To limit copper concentration, the dose of copper in vineyard soil is limited to $8 \mathrm{~kg}$ Cu per hectare in vine cultivation ${ }^{8}$.

Normally copper is nontoxic to mammals ${ }^{9}$, and copper deficiency could even result in inflammation, anemia and other discomforts ${ }^{10}$. However, excessive digestion of copper might cause a series of health problems. Several studies have revealed that too much copper accumulating in human bodies could result in liver cirrhosis, cell hemolysis, anemia, kidney disorders and osteoporosis ${ }^{11-16}$. As such, grapes and grape products that are susceptible to copper might arouse public health concern due to the universal application of copper-based pesticides in viticulture ${ }^{1,17-20}$. Some of these previous studies focused on whether the heavy metal contents exceeded the tolerable daily intake (TDI $)^{21,22}$, and some of them discussed copper distributions in underground and aerial parts of the plants ${ }^{23}$, but few of them discussed the influence of pesticides application or other potential factors (such as environmental pollution) on grapes. In this study, we not only sampled grapes from the main grape-producing areas, but also from e-waste dismantling areas with environmental heavy metal pollution and from home

Institute of Quality Standard and Testing Technology for Agro-Products, The Chinese Academy of Agricultural Sciences (CAAS), Beijing, 100081, China. Correspondence and requests for materials should be addressed to X.S. (email: lixiaomin@caas.cn) 


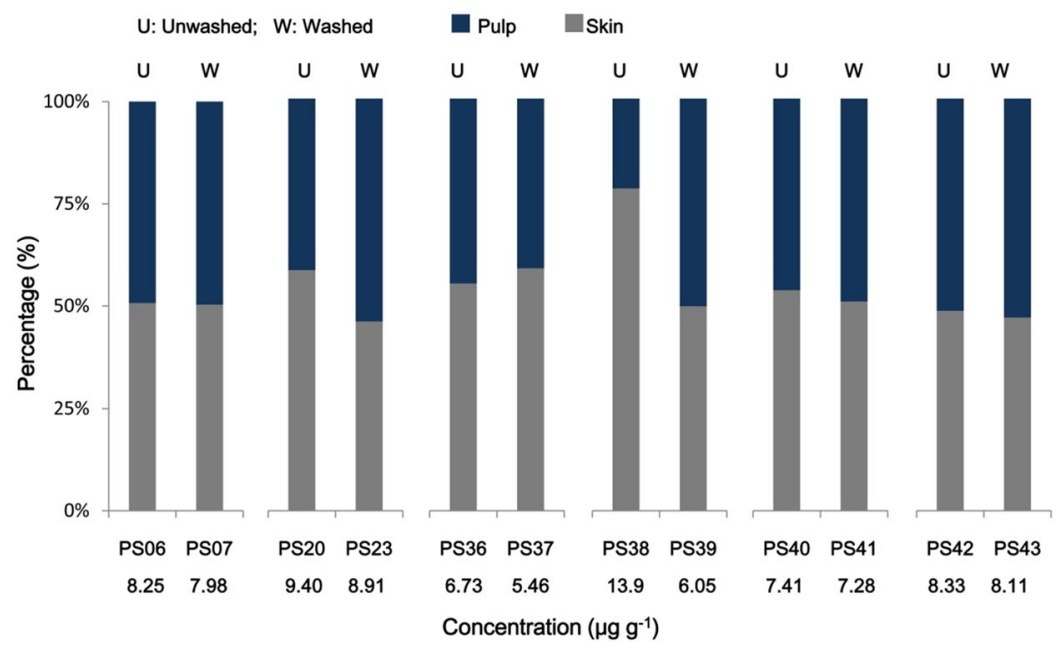

Figure 1. Comparison of copper in paired unwashed and washed grape samples. Data shown below sample name were the total copper concentration in grapes.

courtyard with pesticide-free situation. These sampling areas allow us to compare and analyze copper and other heavy metals in grapes across Chinese market.

Some of the heavy metals are well known for their toxicity, non-biodegradable nature and potential bioaccumulative behavior in human tissues ${ }^{13,24,25}$. It has been demonstrated that excessive intake of heavy metals could result in damage to organs and cause numerous diseases, which were characterized by osteomalacia, renal and nerve dysfunction, cardiovascular problems and so on ${ }^{13,26}$. The main exposure routes to heavy metals for humans are through dietary. Therefore, the tolerate daily intake of these elements in food were strictly restricted by authorities and countries ${ }^{27,28}$. European Commission (EC) have set up regulations to control lead $(\mathrm{Pb})$ and cadmium (Cd) in foodstuffs ${ }^{29}$, and World Health Organization (WHO) also assessed heavy metal toxicity and recommended ingestion ranges to certain amounts ${ }^{30}$. As an important part of dietary, it is necessary to evaluate, monitor and control heavy metals in fruits.

Copper-based pesticide is intensively used in viticulture, but few studies have evaluated heavy metals in grapes with regard to the large-scale application of $\mathrm{Cu}$-based pesticide. In this study, grapes from markets, home yards and e-waste dismantling areas were collected. The major objectives of this article were to assess the levels of copper in grapes across Chinese market and discuss the influential factors. Moreover, six more important heavy metals (chromium (Cr), manganese ( $\mathrm{Mn}$ ), nickel (Ni), metalloid arsenic (As), $\mathrm{Cd}$ and $\mathrm{Pb}$ were simultaneously analyzed. Grapes were separated into skins and pulps for analysis respectively. Factors such as pesticide application, soil pollution and water clean-up process were taken into consideration to trace the sources and fates of heavy metals in grapes. Further, the potential health risk of ingesting heavy metals by consuming grapes was also evaluated.

\section{Results}

In this study, contents of heavy metals in samples were expressed on dry weight base. The moistures of grape skins and pulps were in the range of $74.2-88.9 \%$ and $78.4-92.3 \%$, and the geometric means were $82.8 \%$ and $85.2 \%$ respectively. The concentrations of copper in grape skins and pulps were in the range of $1.83-20.1 \mu \mathrm{g} / \mathrm{g} \mathrm{dw}$ and $1.27-7.74 \mu \mathrm{g} / \mathrm{g} \mathrm{dw}$, with average mean values of $5.22 \mu \mathrm{g} / \mathrm{g} \mathrm{dw}$ and $3.73 \mu \mathrm{g} / \mathrm{g} \mathrm{dw}$, respectively.

Seven grape samples were collected from Taizhou. The mean values of copper in these 7 grape skins and pulps were $5.30 \mu \mathrm{g} / \mathrm{g}$ and $3.10 \mu \mathrm{g} / \mathrm{g}$ respectively, which were in the same level to the average of all samples. Four home grown grapes (pesticide free) showed mean concentrations of copper in skin and pulp to be $5.34 \mu \mathrm{g} / \mathrm{g}$ and $3.21 \mu \mathrm{g} / \mathrm{g}$ respectively, which also were comparable to the mean values obtained from all grape samples.

The water clean-up process was conducted. The differences of copper levels in paired unwashed and washed grape skins and pulps were shown in Fig. 1 , and significant difference has been observed $(\mathrm{p}<0.05)$. Copper levels in all the unwashed skins were higher than in the corresponding washed skins, especially for two paired samples (PS20 and PS23, PS38 and PS39). There were $25.4 \%$ and $72.3 \%$ of copper removed in PS23 and PS39 respectively, which indicated that a certain amount of copper was attached on the grape skin surface and could be washed away. Both of the two grapes were collected from e-waste dismantling areas.

The concentrations of $\mathrm{Cr}, \mathrm{Mn}, \mathrm{Ni}, \mathrm{Cd}, \mathrm{Pb}$ and As in grape skins $(\mathrm{n}=41)$ and pulps $(\mathrm{n}=41)$ from different functional zones were summarized in Table 1. The average concentrations of all the detected heavy metals in grape skins were higher than in pulps (Fig. 2). Considering the detection frequencies of the rest metals, $\mathrm{Cr}, \mathrm{Mn}$ and As were $100 \%$ detected both in grape skins and pulps. $93.6 \%$ of $\mathrm{Ni}$ in grape skins and $51.2 \%$ of $\mathrm{Ni}$ in grape pulps were detected respectively. Geometric means of skin/pulp ratios were 2.15, 3.25, 4.58, 1.01 for $\mathrm{Cr}, \mathrm{Mn}, \mathrm{Ni}$, As, respectively. 


\begin{tabular}{|c|c|c|c|c|c|c|c|c|c|c|c|c|c|c|c|}
\hline \multicolumn{16}{|c|}{ Grapes (dry weight) } \\
\hline & & \multicolumn{7}{|c|}{ Skins $(\mu \mathrm{g} / \mathrm{g})^{\mathrm{a}}$} & \multicolumn{7}{|c|}{ Pulps ( $\mu \mathrm{g} / \mathrm{g})$} \\
\hline & & $\mathbf{C r}$ & Mn & $\mathrm{Ni}$ & $\mathrm{Cu}$ & As & Cd & $\mathbf{P b}$ & $\mathrm{Cr}$ & Mn & $\mathrm{Ni}$ & $\mathrm{Cu}$ & As & Cd & $\mathbf{P b}$ \\
\hline \multirow{3}{*}{$\begin{array}{l}\text { Chinese } \\
\text { market } \\
(\mathrm{n}=29)\end{array}$} & Max & 1.64 & 2013 & 4.00 & 11.6 & 0.95 & 0.20 & 5.11 & 0.46 & 31.0 & 0.16 & 7.72 & 0.67 & 0.04 & 0.37 \\
\hline & Min & 0.08 & 2.51 & N.D. ${ }^{b}$ & 1.83 & 0.1 & N.D. & N.D. & 0.04 & 0.97 & N.D. & 1.41 & 0.03 & N.D. & N.D. \\
\hline & Mean $^{\mathrm{a}}$ & 0.26 & 92.4 & 0.34 & 4.67 & 0.25 & 0.09 & 0.27 & 0.10 & 7.71 & 0.06 & 3.84 & 0.28 & 0.04 & 0.37 \\
\hline \multirow{3}{*}{$\begin{array}{l}\text { E-waste } \\
\text { dismantling } \\
\text { area }(\mathrm{n}=7)\end{array}$} & Max & 0.44 & 104 & 0.56 & 10.8 & 0.43 & 0.02 & & 0.12 & 36.1 & 0.25 & 29 & 0.35 & 004 & N.D. \\
\hline & Min & 0.13 & 9.71 & 0.04 & 1.96 & 0.09 & N.D. & 0.05 & 0.05 & 3.07 & N.D. & 1.27 & 0.07 & N.D. & N.D. \\
\hline & Mean & 0.24 & 63.4 & 0.26 & 5.30 & 0.23 & 0.02 & 0.15 & 0.09 & 18.0 & 0.10 & 3.10 & 0.23 & 0.004 & N.D. \\
\hline \multirow{3}{*}{$\begin{array}{l}\text { Courtyard } \\
(\mathrm{n}=4)\end{array}$} & Max & 0.71 & 29.7 & 0.52 & 9.96 & 0.36 & N.D. & 0.24 & 0.15 & 6.65 & N.D. & 3.71 & 0.15 & N.D. & N.D. \\
\hline & Min & 0.17 & 5.12 & 0.01 & 2.89 & 0.23 & N.D. & 0.03 & 0.11 & 1.70 & N.D. & 2.5 & 0.08 & N.D. & N.D. \\
\hline & Mean & 0.35 & 14.1 & 0.17 & 5.34 & 0.28 & N.D. & 0.15 & 0.12 & 3.58 & N.D. & 3.21 & 0.12 & N.D. & N.D. \\
\hline Chile $(\mathrm{n}=1)$ & & 0.39 & 10.4 & 0.05 & 20.1 & 0.21 & N.D. & N.D. & 0.10 & 2.65 & N.D. & 7.74 & 0.30 & N.D. & N.D. \\
\hline $\begin{array}{l}\text { Average value } \\
(\mathrm{n}=41)\end{array}$ & & 0 & 77.8 & 0.30 & 22 & 0.25 & 0.07 & 0.24 & 0.10 & 9.22 & 0.07 & 3.75 & 0.26 & 0.02 & 0.37 \\
\hline
\end{tabular}

Table 1. Levels of heavy metals in grape skins and pulps from different sampling area in China. ${ }^{\mathrm{a} O n l y}$ the detected values were used to calculate mean values. ${ }^{b}$ N.D. $=$ not detected.
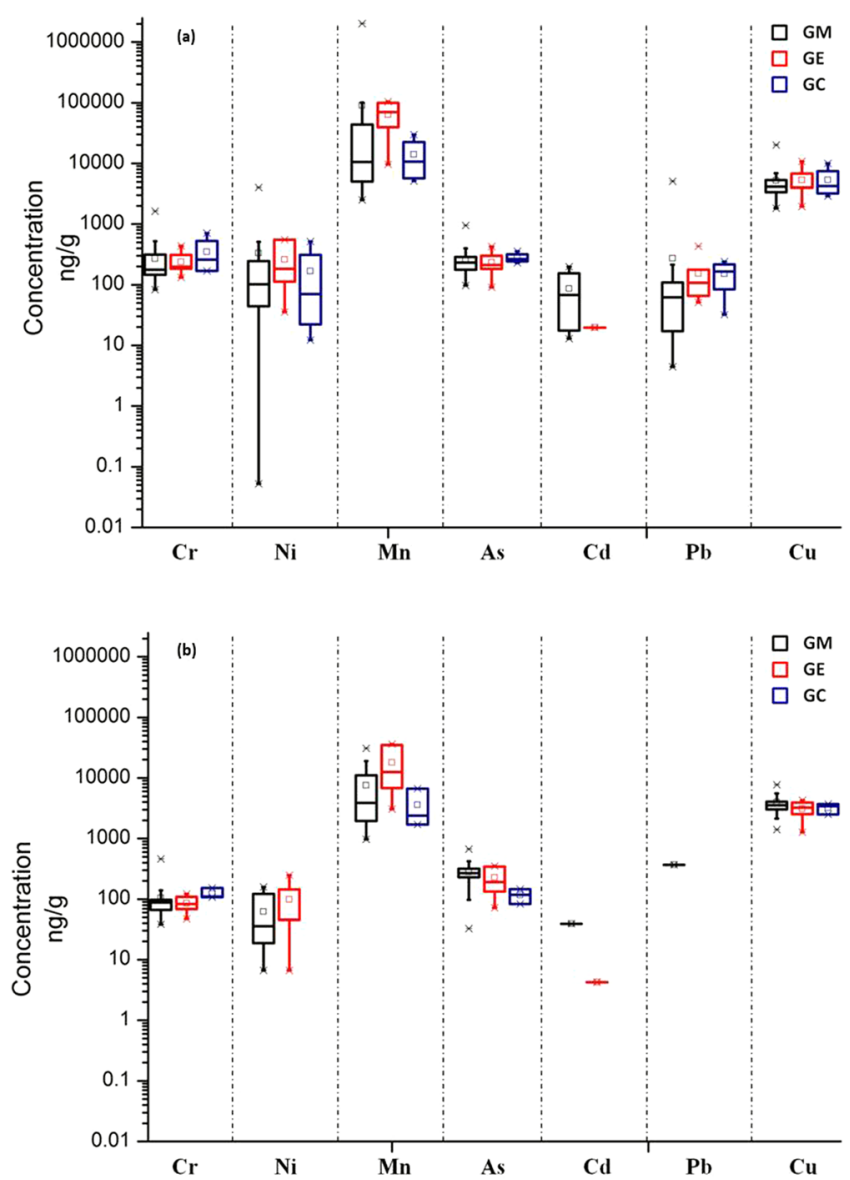

Figure 2. Box-and-whisker plots of $\mathrm{Cr}, \mathrm{Ni}, \mathrm{Mn}, \mathrm{As}, \mathrm{Cd}, \mathrm{Pb}$ and $\mathrm{Cu}$ levels in grape (a) skins and (b) pulps. The box upper and under lines represent 25 th and 75 th percentiles, and three horizontal bars represent 5th, 50th, and 95th percentiles, *represent the $1 \%$ and $99 \%$, represent mean values. GM, GE and GC represent grapes collected from markets, grapes collected from e-waste dismantling areas and grapes collected from courtyards, respectively.

\section{Discussion}

Of all the grape samples analyzed, no sample exceeded the maximum residue limit (MRL) of copper restricted by Chinese national tolerance limit of copper in fruit $(10 \mathrm{mg} / \mathrm{kg})^{31}$, nor exceeded the restriction of European Commission $(20 \mu \mathrm{g} / \mathrm{g})^{32}$. The mean value of copper concentration in pulps was higher than some of the previous 


\begin{tabular}{|c|c|c|c|c|c|}
\hline \multirow[b]{2}{*}{ Country } & \multirow[b]{2}{*}{ Grapes } & \multicolumn{3}{|c|}{ Cu concentrations } & \multirow[b]{2}{*}{ Literature } \\
\hline & & $\min$ & $\max$ & mean & \\
\hline \multirow{2}{*}{ Slovenia } & red grapes & $1.1 \mu \mathrm{g} / \mathrm{g} \mathrm{dw}$ & $10.2 \mu \mathrm{g} / \mathrm{g} \mathrm{dw}$ & $4.2 \mu \mathrm{g} / \mathrm{g} \mathrm{dw}$ & 52 \\
\hline & white grapes & $1.6 \mu \mathrm{g} / \mathrm{g} \mathrm{dw}$ & $8.1 \mu \mathrm{g} / \mathrm{g} \mathrm{dw}$ & $4.7 \mu \mathrm{g} / \mathrm{g} \mathrm{dw}$ & \\
\hline \multirow{2}{*}{ Spain } & red grape & $-^{a}$ & - & $0.49 \mu \mathrm{g} / \mathrm{g} \mathrm{ww}$ & 1 \\
\hline & white grape & - & - & $0.53 \mu \mathrm{g} / \mathrm{g} \mathrm{ww}$ & \\
\hline Egypt & grapes & $5.07 \mu \mathrm{g} / \mathrm{g} \mathrm{dw}$ & $9.15 \mu \mathrm{g} / \mathrm{g} \mathrm{dw}$ & $7.75 \pm 0.90 \mu \mathrm{g} / \mathrm{g} \mathrm{dw}$ & 43 \\
\hline \multirow{2}{*}{ Italy } & red grape & - & - & $11.3 \pm 8.61 \mu \mathrm{g} / \mathrm{g} \mathrm{dw}$ & 18 \\
\hline & white grape & - & - & $7.54 \pm 7.50 \mu \mathrm{g} / \mathrm{g} \mathrm{dw}$ & \\
\hline France & grapes & - & - & $4.5 \mu \mathrm{g} / \mathrm{g} \mathrm{dw}$ & 23 \\
\hline Germany & grape & $6.56 \mu \mathrm{g} / \mathrm{g}$ & $19.9 \mu \mathrm{g} / \mathrm{g}$ & - & 53 \\
\hline Turkey & grapes & - & - & $5.7 \pm 0.1 \mu \mathrm{g} / \mathrm{g} \mathrm{dw}$ & 54 \\
\hline Ukraine & grapes & $1.47 \mu \mathrm{g} / \mathrm{g} \mathrm{dw}$ & $1.72 \mu \mathrm{g} / \mathrm{g} \mathrm{dw}$ & - & 55 \\
\hline China & grape & $3.45 \mu \mathrm{g} / \mathrm{g}$ & $9.16 \mu \mathrm{g} / \mathrm{g}$ & $4.80 \mu \mathrm{g} / \mathrm{g}$ & 56 \\
\hline India & grapes & - & - & $84.4 \pm 0.68 \mu \mathrm{g} / \mathrm{g} \mathrm{dw}$ & 57 \\
\hline \multirow{2}{*}{ China } & grape skins & $1.82 \mu \mathrm{g} / \mathrm{g} \mathrm{dw}$ & $20.1 \mu \mathrm{g} / \mathrm{g} \mathrm{dw}$ & $5.02 \pm 3.18 \mu \mathrm{g} / \mathrm{g} \mathrm{dw}$ & this study \\
\hline & grape pulps & $1.27 \mu \mathrm{g} / \mathrm{g} \mathrm{dw}$ & $7.74 \mu \mathrm{g} / \mathrm{g} \mathrm{dw}$ & $3.74 \pm 1.48 \mu \mathrm{g} / \mathrm{g} \mathrm{dw}$ & this study \\
\hline
\end{tabular}

Table 2. Concentrations of Copper in grapes around the world. ${ }^{a}$ Data not available.

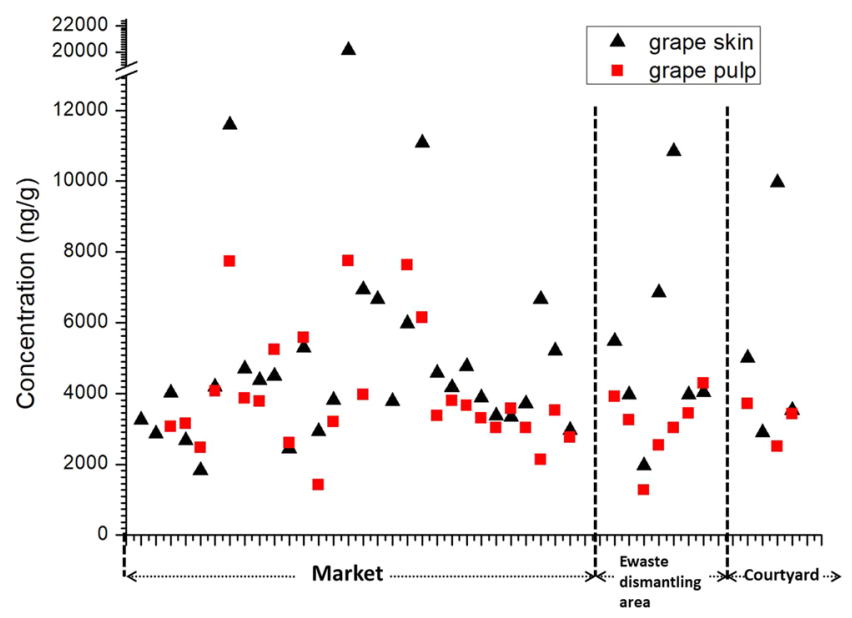

Figure 3. Levels of copper in grape skins and pulps.

studies (Table 2). Renan reported the average concentration of grape pulps to be $0.94 \mu \mathrm{g} / \mathrm{g} \mathrm{dw}$ in Zhejiang Province, China ${ }^{3}$. In Spain, Olalla et al. reported that the copper concentration in grape was $0.52 \mu \mathrm{g} / \mathrm{g} \mathrm{ww}^{1}$. However, copper contents in our study were not as high as the grapes obtained from Italy farms $(11.32 \pm 8.61 \mu \mathrm{g} / \mathrm{g}$ $\mathrm{dw})^{18}$. In order to evaluate the influence of copper-based pesticide on copper levels, we further summarized the copper levels in some other fruits and listed the results in Table S1, Supplementary Information. Some of the listed fruits are sprayed with copper-based pesticide in order to control vine fungal diseases (e.g. apple), and some of them were copper-pesticide free fruits. There were no orders of magnitude difference observed in copper levels among these fruits, expect the fruits from India. And according to these works, concentrations of copper in grapes were in the similar level compared to the other fruits (Table S1, Supplementary Information).

Concentrations of copper in grape skins and pulps from markets, ewaste dismantling area and courtyards were shown in Fig. 3. According to the result, copper concentrations in skins were significant higher than in pulps $(\mathrm{p}<0.01)$, and the geometric mean of skin/pulp ratio $(\mathrm{n}=41$, not including washed samples) was 1.54 . The result suggested that pesticide spray and air deposition might result in higher levels of copper in grape skins, or there were distinctive absorption behaviors for grape skins and pulps. A previous work pointed out that pesticide spray was the main source of copper in grapes ${ }^{18}$. However, it still need more evidence to discuss the influences of the other factors beyond application of pesticides.

In this study, we collected grape samples from an intensive e-waste dismantling area to find out whether the environmental contamination (soil uptake or air deposition) would bring heavy metal pollution into grapes or not. Taizhou is a notorious and intensive e-waste dismantling center which located in Southeast China. The e-waste dismantling history of local area can be traced back to $1980 \mathrm{~s}$, almost focusing on scrapped transformers and other electrical equipment. Due to the dismantling activities, local soil was seriously polluted by heavy metals. However, not as expected, only two grapes had higher copper levels in grapes from e-waste dismantling area. 
The average level of copper in all 7 grape samples from Taizhou was in the same level compared to the average level of all grapes, implying that soil from e-waste dismantling area did not bring in general copper pollution to grapes when compared to the commercial vineyard. The copper concentration in local soil was more than $100 \mu \mathrm{g} / \mathrm{g}$ according to previous report ${ }^{33,34}$, which were much higher than Beijing soil $(29.0 \mu \mathrm{g} / \mathrm{g})^{35}$. It was reported that the copper concentration would be around an average of $30 \mu \mathrm{g} / \mathrm{g}$ in the unpolluted soils $\mathrm{s}^{36}$. However, copper level in Taizhou soil was quite comparable to the copper polluted soils in vineyards ${ }^{37}$. It has been reported that the concentrations of copper in grapes would increase with the age of the vines, but even though only few copper were transported from soils to grapes according to our study. Another study supported our suggestion that the amount of copper which was transferred from soil to plant could only explain a small part of the total copper concentration in plants ${ }^{4}$. Considering the air transport pollutions, levels of copper in total suspended particulate (TSP) in e-waste dismantling area $\left(483 \pm 167 \mathrm{ng} / \mathrm{m}^{3}\right)$ were several times higher than that in Beijing $\left(110 \pm 110 \mathrm{ng} / \mathrm{m}^{3}\right)$ and Taiwan $\left(198.6 \pm 385.4 \mathrm{ng} / \mathrm{m}^{3}\right)^{38,39}$. This TSP-copper was also able to absorb on grape skins. Whether the air deposition will bring in heavy metal pollution to grapes will be discussed later in the clean-up procedure of this study.

Four home grown grapes (pesticide free) were collected to make a comparison to the copper-based pesticide applied grapes. None of these four home grown grapes were sprayed pesticides. Relatively higher copper levels in grape skins were found than pulps. It seems like that grape skins play a better enrichment than grape pulps. Furthermore, the similarity of copper levels in home grown grapes and e-waste dismantling area collected grapes showed that the copper levels were not closely connected to the heavy metal levels of soil. From another point of view, our study suggested that grape might not be a good copper accumulation plant, or the middle environmental levels of copper were rich enough for grapes to absorb and combine to the tissue.

In order to investigate whether copper was attached to the surfaces of grape skin or combined to the tissue, we evaluated the level variation of copper before and after fresh water cleaning. $4.12-72.3 \%$ of copper (average 7.62\%) was removed after cleaning for all the six paired skin samples. As can be seen from Fig. 1, the copper concentrations in unwashed PS38 and PS20 were higher than the other washed samples (PS39 and PS23, respectively). $25.4 \%$ and $72.3 \%$ copper in mass was removed. The copper contents in the rest 4 paired skin samples were almost in the same level. Considering the copper levels in PS38 and PS20 were higher than the other unwashed grape skins, the clean-up procedure might be effective to remove copper in high content samples. During the grape maturity, copper might permeate into grapes and combine to grape tissues rather than stay on the surface of skins. Therefore, washing process might be helpful to remove the copper attached to the surface of the grapes, but not to the combined-to-tissue copper in grape skins. As both PS38 and PS20 were collected from e-waste dismantling areas, the higher copper found in local TSP might also have influences as aforementioned. Further research is needed to make a confirmation.

The limited changes of copper concentrations after clean-up process in other four paired grapes suggested that the withdrawal period of pesticide was long enough. Generally, in order to ensure the fruit was safe to eat, the application of Bordeaux mixture will be stopped about fifteen to twenty days before the grape was sold on market. Previous investigation also suggested that safety withdraw time for grape and grape product was more than 20 days. Normally 40 to 50 days were completely enough to limit copper concentrations below $20 \mu \mathrm{g} / \mathrm{g}$ even in dry year ${ }^{18}$. The rain will also be helpful to clean copper off from grape skins. Before the grape harvest, it is the most rainy days in China, which is helpful to remove heavy metals from grapes. As a result, although the application of pesticides was overdose from time to time, the attached copper on grape surfaces was not at a high level in most of grapes. However, it should also be noticed that washing may only reduce the levels of metals in a smattering part. Once metals were introduced and distributed into tissues, they were hardly to be thoroughly removed under traditional handling techniques ${ }^{40}$. Paradelo et al. investigated the loss of copper-based pesticides during complex physical washing processes, the result of which showed that mean copper loss was $27.0 \%$ for the Bordeaux mixture, and the washing time was not quite related ${ }^{41}$.

The other 5 heavy metals and arsenic in grapes were simultaneously analyzed. Figure 4 described concentrations of $\mathrm{Cr}, \mathrm{Ni}, \mathrm{Mn}, \mathrm{As}, \mathrm{Cd}$, and $\mathrm{Pb}$ in grape skins and pulps from markets, ewaste dismantling area and courtyards, respectively. Level of Mn was found to be the highest among all the detected metals. The average concentrations of $\mathrm{Cr}, \mathrm{Mn}, \mathrm{Ni}$ and $\mathrm{Cu}$ in our study were one order of magnitude higher than a national investigation among French markets ${ }^{42}$. Wilcoxon nonparametric test for matched pairs was conducted to analyze the significant difference of metal levels between grape skins and pulps (Table 3). The result also showed that $\mathrm{Cr}, \mathrm{Mn}, \mathrm{Ni}$ and $\mathrm{Cu}$ were significant higher in grape skins than in pulps. It is unable to perform statistical analysis to evaluate this difference of $\mathrm{Cd}$ and $\mathrm{Pb}$ for their low detection rates. Only $2.44 \%$ of $\mathrm{Pb}$ was detected in grape pulps, but $95.7 \%$ of $\mathrm{Pb}$ was detected in grape skins. It is not difficult to deduce that there is a significant difference between grape skins and pulps for $\mathrm{Pb}$. Although $\mathrm{Cd}$ was rarely detected both in grape skins and pulps, clearly higher level in grape skin was found in Fig. 4. Not as the same as the other heavy metals, As did not show a significant difference between grape skins and pulps, and the result of which were shown in Fig. 4.

The environmental pollution in the e-waste dismantling area was also evaluated for the other heavy metals to see if it has introduced the trace elements into grapes. The levels of $\mathrm{Cr}, \mathrm{Ni}, \mathrm{As}, \mathrm{Cd}$ and $\mathrm{Pb}$ in grape skins and pulps from e-waste dismantling area were very close to those collected from market and courtyard. $\mathrm{Pb}$ was one of the most toxic heavy metals. Comparable $\mathrm{Pb}$ levels were found in our study $(0.31 \mu \mathrm{g} / \mathrm{g})$ and another urban waste dumping area, with an average copper level of $0.4 \mu \mathrm{g} / \mathrm{g}$ in grapes ${ }^{23}$. The $\mathrm{Pb}$ in grapes obtained from an Egypt market survey showed similar level $(0.16 \pm 0.02 \mu \mathrm{g} / \mathrm{g} \mathrm{dw})$, but the level of Cd was one order of magnitude lower $(0.002 \pm 0.001 \mu \mathrm{g} / \mathrm{g} \mathrm{dw})^{43}$. Without direct pesticide spray for these heavy metals, root absorption from water/soil and air deposition might be the two main sources of heavy metals in grapes. Root absorption is closely associated with heavy metal chemical fractions, which were quite different from one heavy metal to another. $\mathrm{Pb}$ is less distributed in exchangeable and soluble fraction ${ }^{44}$, which makes it hard to uptake by plant. In the same time, clean-up experiment showed that $\mathrm{Pb}$ levels in unwashed skins were 3.0 times higher than washed skins, indicating $66.7 \%$ of $\mathrm{Pb}$ was removed after the washing process. Differences in $\mathrm{Pb}$ content of unwashed and washed grape 

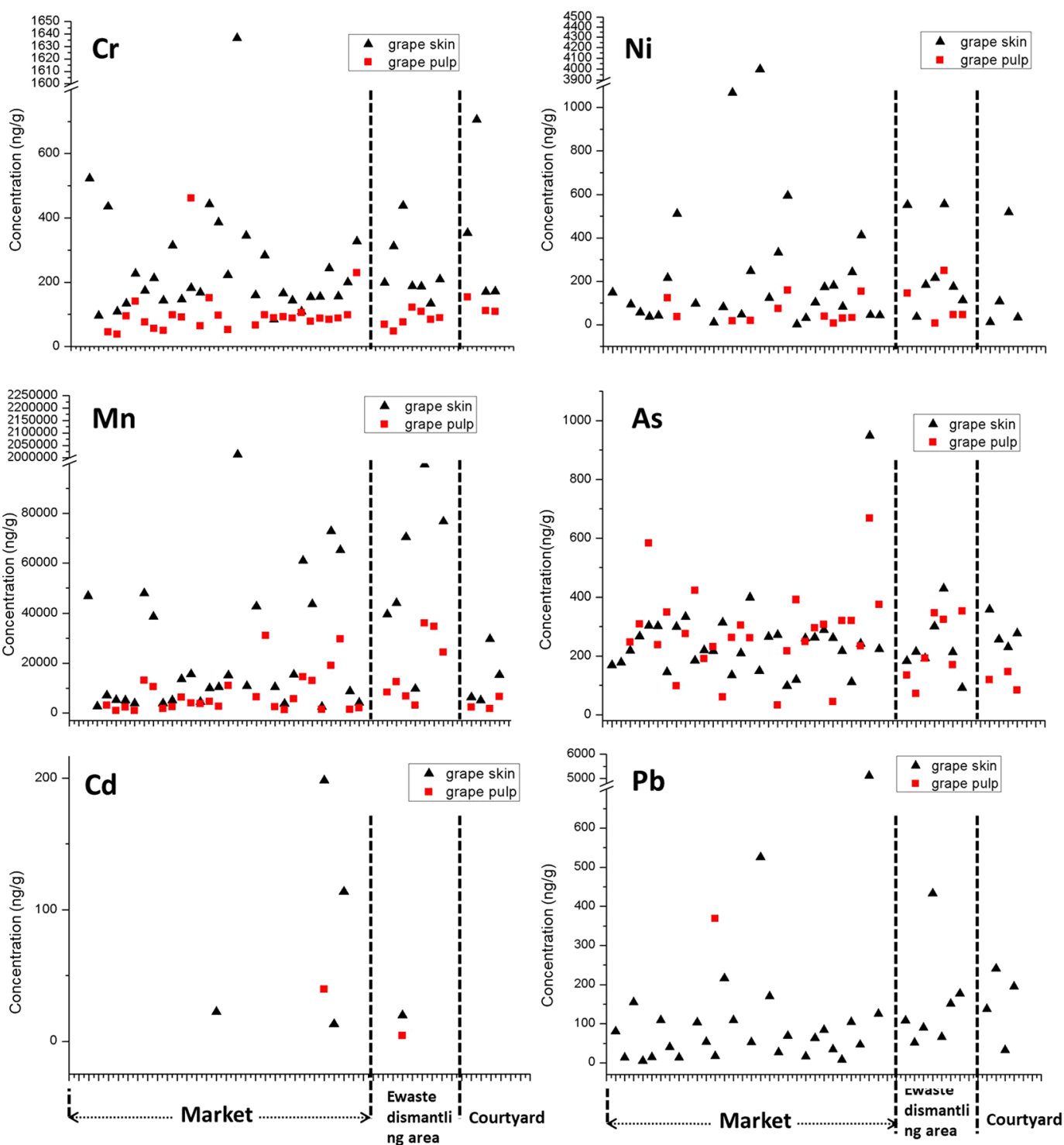

Figure 4. Levels of $\mathrm{Cr}, \mathrm{Ni}, \mathrm{Mn}, \mathrm{As}, \mathrm{Cd}$ and $\mathrm{Pb}$ in grape skins and pulps. The heavy metals under detection limits were left blank.

\begin{tabular}{|l|l|l|l|l|l|l|l|}
\hline & $\mathbf{C r}$ & $\mathbf{M n}$ & $\mathbf{N i}$ & $\mathbf{C u}$ & $\mathbf{A s}$ & $\mathbf{C d}$ & $\mathbf{P b}$ \\
\hline $\mathrm{Z}$ & -4.697 & -5.232 & -3.516 & -3.786 & -0.141 & $\mathbf{- ~}^{\mathrm{a}}$ & - \\
\hline $\mathrm{p}$ value & $\mathrm{p}<0.05$ & $\mathrm{p}<0.05$ & $\mathrm{p}<0.05$ & $\mathrm{p}<0.05$ & $\mathrm{p}>0.05$ & - & - \\
\hline
\end{tabular}

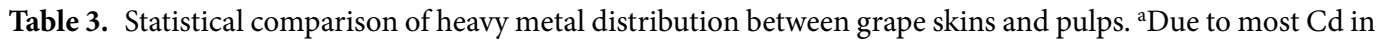
grape skins and pulps and $\mathrm{Pb}$ in grape pulps were under detection limits, so the test values were not given.

skins were also evaluated using the paired t-test. Although no significant difference was found $(\mathrm{p}<0.05)$, the value was very close to it $(\mathrm{p}=0.06)$. So it is conducted that a large portion of $\mathrm{Pb}$ may come from air deposition.

In order to evaluate the intake of heavy metals, we introduced estimated daily intakes (EDI) to evaluate heavy metal ingestion in this study. EDIs of heavy metals were calculated by using the average levels of grape pulps and skins. The EDI equals to the metal concentrations in fruit multiplying by a man's daily intake (presumed to be $500 \mathrm{~g}$ ). In our study, the daily intake of copper through grapes was in the range of $0.11-0.96 \mathrm{mg}$, and the mean value was $0.28 \mathrm{mg}$. This result was lower compared to the WHO guideline, but was higher than an investigation of copper ingestion from fruit by Chinese people ${ }^{45}$. Copper was an essential element which was difficult to establish regulatory guideline, because the dose-response curve of copper was found to be a U-shape ${ }^{15}$. This implied that ingestion of too little or too much copper can both cause adverse health consequences ${ }^{46}$. Based on a variety of analytical data of daily diets, the WHO suggested a dose of $0.7 \mathrm{mg}$ copper for women and $0.8 \mathrm{mg}$ for men per day. 


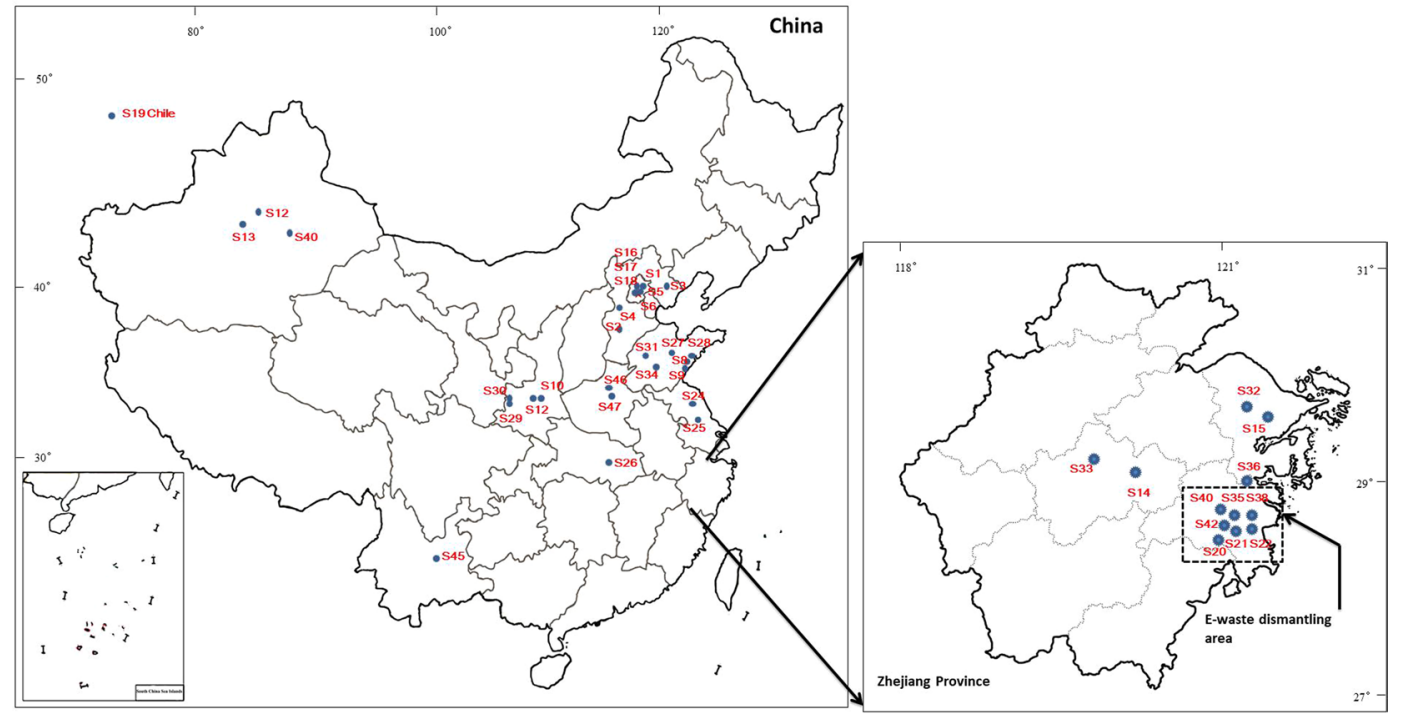

Figure 5. The sampling sites of grapes in China.

This value would totally meet daily requirement of humans. The upper limits of TDI for adults were set to be 10 and $12 \mathrm{mg} /$ day for woman and man respectively ${ }^{30}$. No grape samples exceeded the limitation in our study.

The EDIs of toxic metals, such as $\mathrm{Pb}, \mathrm{Cd}$ and As, were $0.44,0.06$ and $0.33 \mu \mathrm{g} \mathrm{day}^{-1} \mathrm{~kg}^{-1}$ bw respectively. Even the maximum daily intakes of $\mathrm{Pb}, \mathrm{Cd}$ and As were under the TDIs $\left(3.6,1.0\right.$ and $\left.50 \mu \mathrm{g} \mathrm{day}^{-1} \mathrm{~kg}^{-1} \mathrm{bw}\right)$ set by the Food and Agriculture Organization/World Health Organization (FAO/WHO) ${ }^{27}$. Except one pulp sample with a concentration of $\mathrm{Pb}$ reaching $0.37 \mu \mathrm{g} / \mathrm{g} \mathrm{dw}$, all the other pulp samples were below the standards restricting the MRLs to $0.1 \mu \mathrm{g} / \mathrm{g}(\mathrm{Pb})$ and $0.05 \mu \mathrm{g} / \mathrm{g}(\mathrm{Cd})$ in China standard ${ }^{28}$ and European regulations ${ }^{29}$. Excessive ingestion of As is associated with skin and internal cancers, as well as various noncarcinogenic effects ${ }^{47}$. Therefore, the As exposure, which was generally through human diet, caused great public attention and need continuous monitoring. The digestion of As through grapes in the present study were two orders of magnitude lower than the levels of FAO/WHO limit. The results implied that the consumptions of these grapes did not pose a health risk to the consumers, but the contributions from total daily dietary consumption should not be ignored.

\section{Methods}

Forty grape samples (S1-S41, except for S19) were collected from 11 provinces in China (Fig. 5) during 2009 and 2010. Seven samples were collected from e-waste dismantling areas (S20, S21, S22, S35, S38, S40 and S42) and twenty-nine samples were purchased from local markets (all the grapes were locally grown). The rest 4 samples (S16, S17, S18 and S47) were home grown grapes and collected directly from home courtyard. Moreover, one sample was from Chile (S19). In order to evaluate the influences of copper contents in grapes by water-cleanup process, 6 samples were divided into two equal parts and the 6 half portions were carefully washed by fresh water. S7, S23, S37, S39, S41 and S43 were the washed aliquot parts to S6, S20, S36, S38, S40 and S42. The batch of grape samples are collected from the major grape production areas in China (such as Xinjiang, Shandong and Hebei Provinces). Although the production volumes of grapes increased from 855 tonnes in 2010 to 1120 tonnes in 2017 (nearly $31.0 \%)^{48}$, the major grape producing areas did not change a lot over the past decades ${ }^{49}$. Bordeaux mixture is currently employed as a major pesticide for grapes in China for its good efficacy and cost-effectiveness ${ }^{50}$. Heavy metals are known unable to degrade as fundamental elements. Therefore, it indicated that the grape samples collected in the present study were still meaningful nowadays.

The samples were carefully stored and kept in a cooling box packed with ice. The box and its contents were then transported to the laboratory quickly. When the samples arrived, they were manually separated into skins and pulps immediately and stored in a refrigerator under $-20^{\circ} \mathrm{C}$ for 24 hours. The samples were later lyophilized at $-56^{\circ} \mathrm{C}$ under a pressure of 0.05 bar. The dry samples were then grinded to fine powders and sealed in polyethylene bags. Both the wet and dry weights of skins and pulps were recorded and the moisture contents were calculated for skin and pulp samples. The moisture content was defined by the following equation ${ }^{51}$ :

$$
M C=\frac{W W-D W}{W W} \times 100 \%
$$

where $M C$ represents the moisture content, $W W$ and $D W$ were the wet weight and dry weight of samples.

Approximately $0.2 \mathrm{~g}$ dry samples were weighed and carefully transferred to a polytetrafluoroethylene digestion container. Nitric acid ( $3 \mathrm{~mL}$, Merck, Germany) followed by $30 \%$ hydrogen peroxide $(3 \mathrm{~mL}$, Beijing Chemical Company, China) were added into the polytetrafluoroethylene container and the mixture was predigested for 3 hours at $60^{\circ} \mathrm{C}$. The mixture was then further digested using a microwave (CEM Mars-X500, USA), with the following program: ramped at $160^{\circ} \mathrm{C}$ in $10 \mathrm{~min}$ and held for $30 \mathrm{~min}$, then raised to $180^{\circ} \mathrm{C}$ in $10 \mathrm{~min}$ and held 
for $30 \mathrm{~min}$. The resultant solutions were then diluted with Milli-Q water to approximate $40 \mathrm{~g}$. The dilution factor could be calculated by the sample weight and the final dilution weight.

The standard solutions were prepared from $100 \mathrm{mg} / \mathrm{L}$ stock (Agilent, USA) in $2 \%$ nitric acid. The samples were then analyzed by an inductively coupled plasma mass spectrometry (ICP-MS, Agilent 7500, USA). Determinations were performed in triplicate by following previously established methods ${ }^{45}$.

Internal calibration method was used to qualify and quantify real samples. The ranges of our linear standard curves were between 0.5 and $100 \mathrm{ng} / \mathrm{mL}$ for all the metals. 94 samples were determined in three batches. In each batch, two blank samples, two standard reference materials (SRM) and 31-32 samples were analyzed. All the 6 blank samples in 3 batches were under detection limits. Two SRMs including peach leaves (GBW08501) and tea leaves (GBW08513) were analyzed to guarantee the analytical procedures. The results showed a good agreement to the certificate values. Except $\mathrm{Pb}$ was $70.2 \pm 5.1 \%$, the recoveries of $\mathrm{Cu}, \mathrm{Mn}, \mathrm{Cr}, \mathrm{Ni}$ and As were in the range of $79.0-83.4 \%, 96.8-102 \%, 81.2-89.4 \%, 79.9-85.7 \%$ and $97.0-119 \%$. During the ICP-MS analysis procedure, the analytical accuracy was also evaluated by analyzing $10 \mathrm{ppb}$ standard solution for every 20 samples. The mean value and relative standard deviation (RSD) of copper were $9.93 \mathrm{ng} / \mathrm{g}$ and $2.06 \%$, and the RSD of other heavy metals were in the range of $0.9-6.32 \%$.

Statistical analysis was conducted to analyze the distribution and correlation of the studied parameters. The concentration relationships among the detectable heavy metals in grape skins and pulps were analyzed using the nonparametric Wilcoxon test. Paired t-test was conducted to see if there was significant difference between unwashed and washed skins. SPSS 17.0 for Windows (SPSS Inc., 2009) was performed and all the significance level for all the tests was set to $\mathrm{p}<0.05$ unless otherwise mentioned.

\section{Data Availability}

All data included in this study are available upon request by contact with the corresponding author.

\section{References}

1. Olalla, M. et al. Nutritional study of copper and zinc in grapes and commercial grape juices from Spain. Journal of Agricultural and Food Chemistry 52, 2715-2720 (2004).

2. Xu, C. M., Zhang, Y. L., Cao, L. \& Lu, J. Phenolic compounds and antioxidant properties of different grape cultivars grown in China. Food Chemistry 119, 1557-1565 (2010).

3. Renan, L. Effect of long-term applications of copper on soil and grape copper (Vitis vinifera). Canadian Journal of Soil Science 73, 345-347 (1994)

4. Brun, L. A., Maillet, J., Hinsinger, P. \& Pepin, M. Evaluation of copper availability to plants in copper-contaminated vineyard soils. Environmental Pollution 111, 293-302 (2001).

5. Moolenaar, S. W. \& Beltrami, P. Heavy metal balances of an Italian soil as affected by sewage sludge and Bordeaux mixture applications. Journal of Environmental Quality 27, 828-835 (1998).

6. Chaignon, V., Sanchez-Neira, I., Herrmann, P., Jaillard, B. \& Hinsinger, P. Copper bioavailability and extractability as related to chemical properties of contaminated soils from a vine-growing area. Environmental Pollution 123, 229-238 (2003).

7. Tiecher, T. L. et al. Tolerance and translocation of heavy metals in young grapevine (Vitis vinifera) grown in sandy acidic soil with interaction of high doses of copper and zinc. Scientia Horticulturae 222, 203-212 (2017).

8. European Commission. CommissionRegulation (EC) No. 473/2002 amending Annexes I, II and VI to CouncilRegulation (EEC) No. 2092/91 on organic production of agricultural products and indications referring thereto on agricultural products and foodstuffs, and laying down detailed rules as regards the transmission of information on the use of copper compounds. Official Journal of the European Union 075, 21-24 (2002).

9. Flemming, C. A. \& Trevors, J. T. Copper toxicity and chemistry in the environment: a review. Water, Air, and Soil Pollution 44, 143-158 (1989)

10. Linder, M. C. \& HazeghAzam, M. Copper biochemistry and molecular biology. American Journal of Clinical Nutrition 63, 797-811 (1996).

11. Steenland, K. \& Boffetta, P. Lead and cancer in humans: where are we now? American Journal of Industrial Medicine 38, 295-299 (2000).

12. Gaetke, L. M. \& Chow, C. K. Copper toxicity, oxidative stress, and antioxidant nutrients. Toxicology 189, 147-163 (2003).

13. Järup, L. Hazards of heavy metal contamination. British Medical Bulletin 68, 167-182 (2003).

14. Olsson, I. M., Eriksson, J., Oborn, I., Skerfving, S. \& Oskarsson, A. Cadmium in food production systems: A health risk for sensitive population groups. Ambio 34, 344-351 (2005).

15. Stern, B. R. Essentiality and Toxicity in Copper Health Risk Assessment: Overview, Update and Regulatory Considerations. Journal of Toxicology and Environmental Health-Part a-Current Issues 73, 114-127 (2010).

16. Carausu, E. M., Checherita, L. E., Stamatin, O. \& Albu, A. Study of Serum and Saliva Biochemical Levels for Copper, Zinc and Cooper-Zinc Imbalance in Patients with Oral Cancer and Oral Potentially Malignant Disorders and their Prostetical and DSSS (Disfunctional Syndrome of Stomatognathic System) Treatment. Revista De Chimie 67, 1832-1836 (2016).

17. Salvo, F., La Pera, L., Di Bella, G., Nicotina, M. \& Dugo, G. Influence of different mineral and organic pesticide treatments on Cd(II), $\mathrm{Cu}(\mathrm{II}), \mathrm{Pb}(\mathrm{II})$, and $\mathrm{Zn}(\mathrm{II})$ contents determined by derivative potentiometric stripping analysis in Italian white and red wines. Journal of Agricultural and Food Chemistry 51, 1090-1094 (2003).

18. Garcia-Esparza, M. A., Capri, E., Pirzadeh, P. \& Trevisan, M. Copper content of grape and wine from Italian farms. Food Additives and Contaminants 23, 274-280 (2006).

19. Schiavo, D., Neira, J. Y. \& Nobrega, J. A. Direct determination of $\mathrm{Cd}, \mathrm{Cu}$ and $\mathrm{Pb}$ in wines and grape juices by thermospray flame furnace atomic absorption spectrometry. Talanta 76, 1113-1118 (2008)

20. Ivanova-Petropulos, V. et al. Rapid Determination of Trace Elements in Macedonian Grape Brandies for Their Characterization and Safety Evaluation. Food Analytical. Methods 10, 459-468 (2017).

21. Ullah, Z. et al. Potentially toxic elements concentrations and human health risk assessment of food crops in Bajaur Agency, Pakistan. Environmental Earth Sciences 76, 482 (2017).

22. Riaz, A. et al. Mercury contamination in selected foodstuffs and potential health risk assessment along the artisanal gold mining, Gilgit-Baltistan, Pakistan. Environmental Geochemistry and Health 40, 625-635 (2018).

23. Chopin, E. I. B. et al. Factors affecting distribution and mobility of trace elements $(\mathrm{Cu}, \mathrm{Pb}, \mathrm{Zn})$ in a perennial grapevine (Vitis vinifera L.) in the Champagne region of France. Environmental Pollution 156, 1092-1098 (2008).

24. Rehman, U. U., Khan, S. \& Muhammad, S. Associations of potentially toxic elements (PTEs) in drinking water and human biomarkers: a case study from five districts of Pakistan. Environmental Science and Pollution Research 25, 27912-27923 (2018).

25. Saddique, U. et al. Potentially toxic elements in soil of the Khyber Pakhtunkhwa province and Tribal areas, Pakistan: evaluation for human and ecological risk assessment. Environmental Geochemistry and Health (2018). 
26. World Health Organization. Lead. Environmental Health Criteria, Geneva. Vol. 165 (1995).

27. Joint FAO/WHO Expert Committee on Food Additives. Evaluation of certain food additives and contaminants: forty-first report of the Joint FAO/WHO Expert Committee on Food Additives [meeting held in Geneva from 9 to 18 February 1993]. World Health Organization Technical Report Series, 922 (1993).

28. GB 2762-2005. Maximum levels of contaminants in foods. National Standard of the People's Republic of China (2005).

29. European Commission. Commission Regulation No. 1881/2006 of 19 December 2006 setting maximum levels for certain contaminants in foodstuffs. Official Journal of the European Union 364, 5-24 (2006).

30. World Health Organization. Trace elements in human nutrition and health. Geneva: World Health Organization (1996).

31. GB 15199-1994. Tolerance limit of copper in foods. National Standard of the People's Republic of China (1994).

32. European Commission. CommissionRegulation (EC) No. 1410/2003 of 7 August 2003 amending Regulation (EC) No. 1622/2000 laying down certain detailed rules for implementing Council Regulation (EC) No. 1493/1999 on the common organisation of the markets in wine and establishing a Community code of oenological practices and processes. Official Journal of the European Union 201, 9-11(2003).

33. Fu, J. J. et al. High levels of heavy metals in rice (Oryza sativa L.) from a typical E-waste recycling area in southeast China and its potential risk to human health. Chemosphere 71, 1269-1275 (2008).

34. Tang, X. J. et al. Heavy metal and persistent organic compound contamination in soil from Wenling: An emerging e-waste recycling city in Taizhou area, China. Journal of Hazardous Materials 173, 653-660 (2010).

35. Xia, X. H., Chen, X., Liu, R. M. \& Liu, H. Heavy metals in urban soils with various types of land use in Beijing, China. Journal of Hazardous Materials 186, 2043-2050 (2011).

36. Adriano, D. C. Trace elements in terrestrial environments: Biogeochemistry, bioavailability, and risks of metals. Springer (2001).

37. Komarek, M., Cadkova, E., Chrastny, V., Bordas, F. \& Bollinger, J. C. Contamination of vineyard soils with fungicides: A review of environmental and toxicological aspects. Environment International 36, 138-151 (2010).

38. Okuda, T. et al. Daily concentrations of trace metals in aerosols in Beijing, China, determined by using inductively coupled plasma mass spectrometry equipped with laser ablation analysis, and source identification of aerosols. Science of the Total Environment 330, 145-158 (2004).

39. Deng, W. J. et al. Atmospheric levels and cytotoxicity of PAHs and heavy metals in TSP and PM2.5 at an electronic waste recycling site in southeast China. Atmospheric Environment 40, 6945-6955 (2006).

40. Morgan, J. N. Effects of processing of heavy metal content of foods. Advances in Experimental Medicine \& Biology 459, 195-211 (1999).

41. Paradelo, M. et al. Simulating washoff of $\mathrm{Cu}$-based fungicide sprays by using a rotating shear device. Journal of Agricultural and Food Chemistry 56, 5795-5800 (2008).

42. Noel, L. et al. $\mathrm{Li}, \mathrm{Cr}, \mathrm{Mn}, \mathrm{Co}, \mathrm{Ni}, \mathrm{Cu}, \mathrm{Zn}, \mathrm{Se}$ and Mo levels in foodstuffs from the Second French TDS. Food Chemistry 132, 1502-1513 (2012).

43. Radwan, M. A. \& Salama, A. K. Market basket survey for some heavy metals in Egyptian fruits and vegetables. Food and Chemical Toxicology 44, 1273-1278 (2006).

44. Pichtel, J., Kuroiwa, K. \& Sawyerr, H. T. Distribution of $\mathrm{Pb}, \mathrm{Cd}$ and $\mathrm{Ba}$ in soils and plants of two contaminated sites. Environmental Pollution 110, 171-178 (2000).

45. Zhu, H., Wang, J. \& Chen, R. Food concentrations and dietary intakes of elements for Chinese man. Chinese Journal of Radiation Mediation and Protection 6, 378-384 (2000).

46. Dorsey, A., Ingerman, L. \& Swarts, S. Toxicological profile for copper. U.S. Department of Health \& Human Services, Public Health Service, Agency for Toxic Substances and Disease Registry (2004).

47. Mushak, P. \& Crocetti, A. F. Risk and revisionism in arsenic cancer risk assessment. Environmental Health Perspectives 103, 684-689 (1995).

48. MOA, Ministry of Agriculture and Rural Affairs of the People's Republic of China, http://www.moa.gov.cn/ (2018).

49. Mu, W. S., Li, C. C., Gao, Y. \& Feng, J. Y. Reaearch on the spatial features of grape production in China. Chinese Journal of Agricultural Resources and Regional Planning 37, 168-176 (2016).

50. Zhang, F. Q. \& Wei, X. G. Study on the application technology of Bordeaux mixture in Viticulture. Morden. Agriculture 9, 30-31 (2015).

51. AOAC. Official methods of analysis (14th ed.). Washington, DC: Association of Official Analytical Chemists (1984).

52. Kristl, J., Veber, M. \& Slekovec, $\mathrm{M}$. The contents of $\mathrm{Cu}, \mathrm{Mn}, \mathrm{Zn}, \mathrm{Cd}, \mathrm{Cr}$ and $\mathrm{Pb}$ at different stages of the winemaking process. Acta Chimica Slovenica 50, 123-136 (2003).

53. Zhu, F. M., Du, B., Li, F. Y., Zhang, J. C. \& Li, J. Measurement and analysis of mineral and heavy metal components in grape cultivars by inductively coupled plasma-optical emission spectrometer (ICP-OES). Journal Fur Verbraucherschutz Und LebensmittelsicherheitJournal of Consumer Protection and Food Safety 7, 137-140 (2012).

54. Soylak, M., Cihan, Z. \& Yilmaz, E. Heavy metal contents of organically produced, harvested, and dried fruit samples from Kayseri, Turkey. Environmental Monitoring and Assessment 185, 2577-2583 (2013).

55. Vystavna, Y., Rushenko, L., Diadin, D., Klymenko, O. \& Klymenko, M. Trace metals in wine and vineyard environment in southern Ukraine. Food Chemistry 146, 339-344 (2014).

56. Fang, B. \& Zhu, X. Q. High content of five heavy metals in four fruits: Evidence from a case study of Pujiang County, Zhejiang Province, China. Food Control 39, 62-67 (2014).

57. Verma, Y. \& Rana, S. V. S. Assessment of cadmium, chromium, and copper levels in market fruit samples in Meerut, North India. Toxicological and Environmental Chemistry 96, 1516-1522 (2014).

\section{Acknowledgements}

This work was supported by the National Key Research and Development Program of China (2017YFC1600302), the National Natural Science Foundation of China (No. 21777190; No. 21707164), and the State Key Laboratory of Environmental Chemistry and Ecotoxicology (KF2015-20).

\section{Author Contributions}

X.L. designed and performed the experiments. S.D. and X.L. analyzed the data. S.D. wrote and X.S. reviewed the manuscript.

\section{Additional Information}

Supplementary information accompanies this paper at https://doi.org/10.1038/s41598-018-34767-z.

Competing Interests: The authors declare no competing interests.

Publisher's note: Springer Nature remains neutral with regard to jurisdictional claims in published maps and institutional affiliations. 
(i) Open Access This article is licensed under a Creative Commons Attribution 4.0 International License, which permits use, sharing, adaptation, distribution and reproduction in any medium or format, as long as you give appropriate credit to the original author(s) and the source, provide a link to the Creative Commons license, and indicate if changes were made. The images or other third party material in this article are included in the article's Creative Commons license, unless indicated otherwise in a credit line to the material. If material is not included in the article's Creative Commons license and your intended use is not permitted by statutory regulation or exceeds the permitted use, you will need to obtain permission directly from the copyright holder. To view a copy of this license, visit http://creativecommons.org/licenses/by/4.0/.

(C) The Author(s) 2018 